\title{
Textual and Interpersonal Differences between a News Report and an Editorial
}

\author{
Anne McCabe and Karl Heilman \\ Saint Louis University, Madrid Campus \\ mccabea@madrid.slu.edu
}

\begin{abstract}
While news reports and editorials may center on very similar experiential content, obviously, their purposes are very different: to inform in the case of the report, and to argue for a particular line of thought on a given situation in the editorial. This paper demonstrates how systemic functional linguistics (SFL) can highlight just how these different ends are achieved linguistically, focusing on the textual meta-function through Theme choice and through the use of textual adjuncts, and on the interpersonal meta-function, through choices in the system of APPRAISAL, especially through the sub-systems of ATTITUDE and ENGAGEMENT. Results from analysis of a news report and an editorial show that the editorial indeed does make recourse to more overtly present interpersonal devices; this is not to say that the news report disguises the authorial presence entirely, as textual devices, such as conjuncts like however, indicate what a writer's expectations of his/her readers are.
\end{abstract}

\section{Introduction}

The written language offers a wide variety of grammatical tools to mediate an author's intended message. In newspapers, as in other kinds of texts, events that take place out there in the "real" world are expressed through the linguistic choices that reporters and editorialists make. That is, events are reconstructed as text through discourse. This reconstruction involves linguistic choices at many turns and levels in the unfolding of the discourse. Systemic functional linguistics (henceforth SFL) (cf. Halliday and Matthiessen 
2004) is a linguistic theory which allows the analyst to shed light on just how it is these choices interact with the social context to imbue texts with the meanings that are expressed. One of the main assumptions of SFL is that language serves three main purposes: the experiential (or ideational), through which language users express their view of the world; the interpersonal, through which language users establish and maintain social contact; and the textual, which allows for the first two to be brought together and organized in a way that is communicatively effective.

In this paper, we focus on the interpersonal and textual meta-functions to demonstrate the ways in which a news reporter and an editorialist make linguistic choices to express what is essentially the same, or similar, experiential content in very different ways, with seemingly different ends: to report or to persuade. A reporter purportedly has the mission of presenting events that took place out there in the world in as objective a way as possible, while an editorialist has the express purpose of providing commentary, or evaluating, those events. For purposes of demonstration, we have chosen two different texts with a similar subject matter, tension in the Middle East, a news article and an editorial piece from the New York Times, which were published on the same day. We use these to analyze the ways in which a reporter and an editorialist make choices in the textual component through Theme and textual adjunct choices, and in the interpersonal component through expressions of appraisal and use of modality, to show how these differing ways of writing the news can be achieved through language. We do not attempt to suggest that these choice types are typical of all editorials and news reports; rather we wish to show the value of the linguistic theory for elucidating the ways in which experiential meaning is encoded along with interpersonal intent through the textual function. Before turning to that demonstration, we provide some background on the SFL concepts that are used to carry out the analyses.

\section{The Textual Component}

\subsection{Theme}

Halliday writes: "the 'textual' component in language is the set of options by means of which a speaker or writer is enabled to create texts" (Halliday 1994: 161). One key choice in the textual configuration of discourse is that of what will appear in Theme position; indeed, for Halliday (1985: 53), "the textual function of the clause is that of constructing a message" and the Theme/Rheme structure is the "basic form of the organization of the clause as message". In the organization of discourse, then, an important concern is which participant, process or circumstance will be chosen as the ideational point of departure for the message. According to Halliday, the Theme "is the element which serves as the point of departure of the message" (Halliday, 1994: 37). While this conception of Theme may seem strictly positional, Fries (1983: 118) makes the point that "there are good and sufficient internal grammatical reasons to say that the beginning is special for some reason" and goes on to argue that "initial position in the sentence, or sentence level Theme, means 
"point of departure of the sentence as message'" (ibid: 119, emphasis added). Martin (1992) provides evidence which indicates that "point of departure does indeed mean something more than coming first" (151).

For Halliday, Theme "provides the environment for the remainder of the message, the Rheme." (Halliday, 1994: 67). Davies (1997) echoes this when he explains that the Theme initiates "the semantic journey" of the clause, and he adds that if a different starting point is chosen for the journey, a different journey results (Davies, personal communication). Thus, through analysis of the text itself and its Theme/Rheme structure "...we can gain an insight into its texture and understand how the writer made clear to us the nature of his underlying concerns" (Halliday, 1994: 67).

In accord with the three metafunctions of language, the experiential, the interpersonal, and the textual, there are also different types of Theme - topical, interpersonal, and textual. All clauses contain a topical Theme, or some experiential element: either a participant, a circumstance or a process (Halliday, 1994: 52). These are the elements of the system of transitivity, which is "the set of options relating to cognitive content, the linguistic representation of extralinguistic experience, whether of the phenomena of the external world or of feelings, thoughts and perceptions" (Halliday, 1967: 199). The experiential component is:

the linguistic expression of the speaker's experience of the external world, including the inner world of his own consciousness - his emotions, perceptions and so on. This component of the grammar provides a conceptual framework for the encoding of experience in terms of processes, objects, persons, qualities, states, abstractions and relations; it is sometimes referred to as 'cognitive', and experiential meaning as 'cognitive meaning', although as suggested earlier all components presuppose a cognitive level of organization...The term 'experiential' makes it clear that the underlying function is seen not as the expression of 'reality' or 'the outer world' but as the expression of patterns of experience; the content given to an utterance by this portion of the language system derives from the shared experience of those participating in the speech situation. (Halliday, 1968: 209, emphasis added).

Thus, the Theme of the clause, which formally is the initial experiential element of the clause, functionally combines the expression of the speaker's perception of reality and the concerns of the speaker to communicate that perception of reality to the listener (McCabe and Alonso Belmonte, 2000). This combination of concerns is heightened above all in cases in which the main intent of the speaker is informational, to pass on information about the world. However, "the priority concerns, discoursal or clausal, of a speaker or writer need not be ideational" (Berry, 1996: 19); she refers to Brown and Yule (1983: 141-3) and their analysis of a passage of spoken English, in which the interactional aspect, through the subject pronouns $I$ and you are thematized. The main concerns in this spoken passage are interpersonal. Furthermore, as mentioned above and illustrated below, text producers also may choose a textual and/or interpersonal element as their point of departure. 


\subsection{Theme Illustrated}

\subsubsection{Simple Theme}

For Halliday, the topical Theme of the declarative clause in English consists of one structural element functioning as a participant, process or circumstance in the clause, as exemplified in Table 1.

\begin{tabular}{|ll|}
\hline \multicolumn{1}{|c|}{ Type } & \multicolumn{1}{c|}{ Token } \\
\hline \hline Participant & $\begin{array}{l}\text { The Palestinian Authority is planning to hold elections in just three months. } \\
\text { ('Summertime in Gaza') }\end{array}$ \\
\hline Circumstance & $\begin{array}{l}\text { In a conversation lasting more than an hour, Mr. Sharon argued that } \\
\text { European nations negotiating with Iran were softening their position... } \\
\text { (Sanger) }\end{array}$ \\
\hline Process & $\begin{array}{l}\text { and may be willing to allow it to hold on to technology to enrich uranium. } \\
\text { (Sanger) }\end{array}$ \\
\hline
\end{tabular}

Table 1. Types and tokens of topical Theme. ${ }^{1}$

In the case of a nominal group as Theme, this may coincide with the Subject of the clause, as in the Participant example above, and in English, this is considered to be the unmarked option for Theme choice. Marked options in English include starting off with a Circumstance, as in the example in Table 1, as these can be positioned elsewhere in the clause. The most marked option in English for Theme choice is a nominal group functioning as Complement, e.g.: "Of juvenile delinquency we do not hear much", of which there were not examples in the texts we analyzed for this paper.

\subsubsection{Multiple Theme}

In addition to the Simple Theme, there are other elements which can be thematic, yet which do not use up all of the thematic potential of the clause. We have seen that a simple Theme consists of some experiential (participant, process or circumstance) element. In addition to the experiential element, a text producer may decide to make thematic some textual or interpersonal element of the clause. These other elements can be divided into two groups: 1) textual, which includes continuative, structural and conjunctive elements, which provide links between ideas; 2) interpersonal, which is any combination of vocative, modal or mood-marking elements, which provide commitment to or comment on the proposition encoded in the clause. Textual and interpersonal Themes are exemplified here in that order, however, as textual, and probably as interpersonal: (in Table 2, the textual and 
interpersonal Themes are italicized and underlined; the experiential Themes are also italicized):

\begin{tabular}{|ll|}
\hline \multicolumn{1}{|c|}{ Type } & \multicolumn{1}{c|}{ Token } \\
\hline \hline Textual & $\begin{array}{l}\text { However }, M r . \text { Sharon gave no indication that Israel was preparing to act } \\
\text { alone to attack Iranian nuclear facilities. (Sanger) }\end{array}$ \\
\hline Interpersonal & Probably no single cause can provide the answer, \\
\hline
\end{tabular}

Table 2. Other types of Theme

Conjunctive and modal adjuncts are outside of this experiential structure of the clause as they have no status as participant, process or circumstance. And, according to Halliday (1994: 53), until a participant, process or circumstance appears, "the clause still lacks an anchorage in the realm of experience". However, adjuncts are thematic given that the speaker/writer can choose to place them in different places in the clause; for example, it would be possible to rewrite the above clause as:

Mr. Sharon, however, gave no indication...

or even:

Mr. Sharon gave no indication, however, that Israel...

thus not giving this textual adjunct thematic prominence.

Another type of textual theme which occurs in the data analyzed here is that of conjunction, including the kind that link (paratactic), such as and, or, either, neither, but, yet, so, then etc. (Halliday and Matthiessen 2004: 81) and or those that bind (hypotactic), such as when, while, before, after, until, because, if, although, unless, etc. (ibid). These operate syntactically in a different way from textual adjuncts, as conjunctions must be clauseinitial. These two types of Theme are illustrated below (the textual Themes are italicized and underlined; the experiential Themes are also italicized):

Textual Theme (paratactic conjunction)

American officials said the evidence Mr. Sharon presented, including aerial photographs of sites in Iran, was neither startling nor new to Mr. Bush. But they said the prime minister was clearly pressuring Mr. Bush not to allow the European negotiations with Iran to drag on. 
Textual Theme (hypotactic conjunction)

Unless the Palestinians want Gaza to be the last Israeli withdrawal instead of the first, it would behoove them to act sensibly.

Thus, clauses can consist of multiple Themes, i.e. any combination of textual, modal and experiential Themes.

\section{APPRAISAL ${ }^{2}$ and Modality}

The system of APPRAISAL has been developed by Jim Martin, Peter White and others within the school of SFL theory. A comprehensive overview of the theory can be found at White 2005a, and in Martin and Rose 2003. From work carried out in the 80s and 90s for the Write It Right project of the NSW Disadvantaged Schools Program in Australia, where these researchers along with others explored the literacy requirements of the discourses across the curriculum, White concluded that "across all the discourse domains it proved necessary to explore in what contexts, by what linguistic means and to what rhetorical ends writers pass value judgements, attribute their propositions to outside sources or modalise their utterances" (White,2005b) These three linguistic means is precisely what we are interested in here. We look at each of these evaluative resources in turn.

\subsection{Attitude}

Within the system of APPRAISAL, how writers pass value judgements corresponds to the system of ATTITUDE, which refers to those meanings that provide reference to either emotional responses or to systems of values. Iedema et al. explain that subjective texts include more overt tokens of APPRAISAL: "In the subjective text, at least some of the author's value judgements are explicitly revealed in the language. In contrast, the strictly "objective" text is constructed in such a way that there is no explicit linguistic evidence of the author's value judgements". Thus an author will not tend to encode linguistically any value judgements when reporting on events.

The system of ATTITUDE itself is divided into 3 subsystems, as explained in Table 3 (White, 2005b).
Subsytem
Explanation

\begin{tabular}{|ll|}
\hline \hline AFFECT & indicates how some phenomenon affected the speaker emotionally \\
\hline JUDGEMENT & shows an evaluation of human behavior with respect to social norms \\
\hline
\end{tabular}




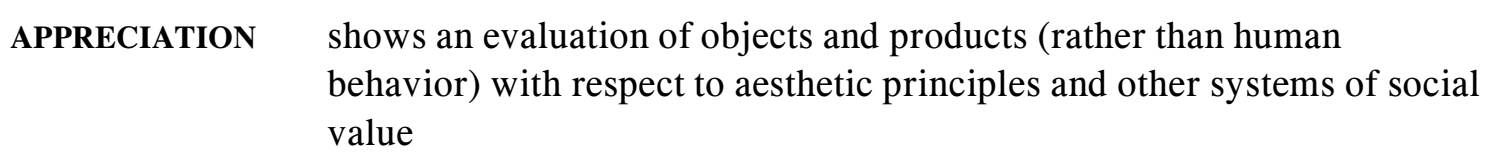

Table 3. Appraisal: System of ATTITUDE

These meanings find expression through language in several ways. For example ${ }^{3}$ :

\section{AfFect:}

adverbials: calmly and unassumingly

attributes: I felt uncomfortable, I was nervous

nominals: to my surprise.

verbs: Israel fell in love; listened with clenched teeth (both from "Summertime in Gaza”)

\section{JUDGEMENT:}

adverbials: handled properly; act sensibly (both from "Summertime in Gaza")

attributes: absolutely correct ("Summertime in Gaza")

nominals: bane of Israel ("Summertime in Gaza")

verbs: Mr. Sharon gave no ground ("Summertime in Gaza")

\section{Appreciation:}

similar to previous categories, but an evaluation of products: controversial plan; $a$ July to remember (both from "Summertime in Gaza")

\subsection{EngAGEMEnT and Modality}

White (2005a) distinguishes within the system of ENGAGEMENT two main types of utterances: monoglossic and heteroglossic. Monoglossic utterances suggest that there is no other view in existence, and are typically encoded as unmodalized declarative clauses, such as:

a) "American officials have interpreted the evidence differently" (Sanger)

b) "The session at the ranch also included some references to Iran's growing missile program" (Sanger)

Heteroglossic utterances, on the other hand, suggest that there are other possible interpretations, or points of view, either similar or different, with respect to the proposition encoded in the utterance. There are many ways of indicating heteroglossia linguistically, such as projection (or providing information through the voice of another, either through reported or indirect speech), modal adjuncts (e.g. admittedly, clearly, certainly, etc.) 
modality, and rhetorical questions. Some examples from the data analyzed here are:

c) "but it certainly will be vocal and perhaps violent" ("Summertime in Gaza")

d) "they seem more willing to allow some uranium enrichment, under strict monitoring" (Sanger)

e) "' 'In light of all these tragedies, do we also deserve this punishment?' he asked". ("Summertime in Gaza")

f) "American officials said the evidence Mr. Sharon presented, including aerial photographs of sites in Iran, was neither startling nor new to Mr. Bush”. (Sanger)

In example c), the editorialist attempts to close down other possible views by suggesting the certainty of the proposition that the opposition will be vocal, while at the same time he opens up the possibility of disagreement on the possible violence of that same protest. In example d), Sanger, the correspondent, suggests that others might interpret the European position differently, by suggesting that they "seem more willing", rather than writing "they are more willing". In example e), the editorialist uses projection to put forth a proposition, which is itself is encoded in a rhetorical question, on the part of an Israeli settler in one of the areas to be evacuated asks a question which he expects a "no" response to: how could hard-working settlers deserve a punishment? In example e), Sanger also uses projection to distance himself from the proposition; Sanger himself is not saying that the evidence was new for Bush; he is suggesting that anonymous American officials say this.

As we can see, the use of modality is a key way in which writers provide either a monoglossic or a heteroglossic slant on the propositions they encode. An unmodalized declarative clause "encourages the reader to assume that the proposition is unproblematic and that it enjoys broad consensus" (Coffin, 2002: 510). Modality, on the other hand, allows writers to "acknowledge the contentiousness of a particular proposition, the willingness ... to negotiate with those who hold a different view, or the deference of the speaker for those alternative views" (White,2005b). A modalized proposition such as "...the Gaza withdrawal could re-energize prospects for peace..." ("Summertime in Gaza") offers a heteroglossic view of the proposition. Thus, by including could, the writer recognizes that there are "divergent heteroglossic positions" (White, 2005b), or multiple points of view, on the proposed statement. In other words, a modalized declarative "unlike the positive declarative, does not assume or simulate solidarity between writer and reader' (Coffin, 2002).

Thus the above examples show the myriad of ways that a speaker/writer may show that there are other possible interpretations of the situation, either opening up these possibilities, as in d) through modality, or attempting to shut down the existence of alternative interpretations, as in c) through the modal adjunct certainly. A writer can also choose a monoglossic unmodalized declarative structure, which indicates that the proposition is 
something about which there is consensus, and therefore aligns the writer and the reader in agreement.

\section{Other studies}

Other research on newspaper texts links author purpose to Theme choice. Francis (1990) analyzed news reports, on the one hand, and news editorials and letters, on the other, to determine whether there exist differences in Theme choices. With respect to textual Themes, Francis found similarities across the different news genres. However, with respect to interpersonal Themes, Francis (1990) found a higher frequency in editorials and letters than in news reports, as the first two news genres are more "personal and evaluative, as well as more concerned with persuasion than information, [so] there is likely to be more direct interaction between writer and reader" (61). Francis also noted a higher frequency of sayers (people quoted or whose words were reported on) in Theme position in the news reports.

Hawes and Thomas (1996) compare editorial articles from The Times, an "ancient and respectable organ of the establishment" (ibid: 159) with The Sun, "know for its sensationalist scandalmongering". Included in their study is an analysis of the discourse participants encoded in the Themes of the clauses, as well as the use of marked Themes. They found that The Sun used many more visible discourse participants (e.g. "The Sun", "We") in Theme position than did The Times; a sense of impartiality is conveyed by the latter newspaper, and a sense of candidness and outspokenness by the former. They also found differences in pronoun use; this they relate to Bernstein's (1966) restricted code, which employs more pronouns, and elaborated code, which employs more content words. The higher pronoun count in The Sun is closer to a restricted code, which they take as a reflection of its status as a working class paper; on the other hand, the higher lexical content in The Times, which they attribute to a middle class mode having also academic overtones. Furthermore, Hawes and Thomas note a difference between editorials in The Sun and The Times in modal Adjunct use in Theme position: $3.6 \%$ and $1.8 \%$ respectively. A cursory glance at the modal Adjuncts which Thomas and Hawes (1996: 126) found in their study shows that the majority express probability: of course, certainly, naturally, by no means, surely, indeed. Thomas and Hawes (ibid: 125) note that several of these expressions "reinforce the "self-evident" image of what is being presented, telling the reader their argument is beyond question".

When media texts are analyzed through APPRAISAL the notion of subjectivity vs. objectivity is illuminated. White suggests that news reports $d o$ contain allegations, claims, accusations and so on, yet they do so through other people's voices, by quoting the players in a given news story: "Attribution then, is said to quarantine the journalist author from 'contamination' by this obviously subjective material” (White, no date). Furthermore, in an in-depth analysis of newspaper texts (White 1998), White distinguishes between a reporter voice, in which no unattributed judgements are to be made, and a writer voice, 
which he divides into correspondent and commentator. When writing in the latter voice, journalists can encode explicit judgements without attribution. However, he notes that in political reporting often the voices alternate, and more so in the case of the correspondent; that is, the correspondent lets his/her presence peek through in the text. Caldas-Coulthard (1994) points out that both direct and indirect reporting of others' words in the news "have the function of legitimizing what is reported" (303); she also points out that writers "are extremely powerful" given that they can choose whose words and which words are "most convenient for them in terms of their aims and ideological point of view" (ibid).

\section{Analysis through SFL}

News articles attempt to provide the aura of objectivity, whereas editorials are put forth as opinions. From the above discussion, then, we would expect some differences in linguistic choices in these two types of journalistic texts with respect to Theme and to APPRAISAL. We would expect in news articles that authors would choose as points of departure unmarked Themes, and to avoid the use of interpersonal Theme. Thus, by implication, we would not expect readers of editorials to be surprised by the inclusion of more marked Themes and interpersonal Themes, and modal adjuncts. Thus, we would expect thematic choices to differ across the two genres, given their different purposes.

With respect to APPRAISAL and journalistic texts, we would expect the same to hold through. Reporters can indicate heteroglossia through projection, and, indeed, as mentioned above, Francis found a fairly high amount of reporting of others' words in her study. However, we expect a news report to be straightforward, matter of fact, to present the facts, as it were, and facts we would expect to be presented as monoglossic, as not open to debate. Given that the purpose of a news story is to give the appearance of objectivity, we would expect it to encode any contentious proposals through attribution to other sources (that is to report on what other people say); thus, one would not expect to find explicit or implicit tokens of judgement, or appreciation for that matter, in a news story unless there are encoded through projection. On the other hand, editorials, one would expect, would make recourse to other heteroglossic devices, such as modality and modal adjuncts, and would probably play down projection, as editorialists are presenting their own views on a topic. At the same time, we would expect editorialists to provide their opinions on behaviors and artifacts through attitudinal language, especially within the systems of JUDGEMENT and APPRECIATION.

To test for these kinds of differences, two different texts with a similar subject matter, tension in the Middle East, were analyzed, a news article and an editorial piece from the New York Times, which were published on the same day. These texts appear in Appendix A. 


\section{Results and Discussion}

\subsection{Results for Theme}

Table 4 provides the percentages (based on the total number of clauses) of the in terms of the frequency of textual and interpersonal Themes, as well as the topical marked Themes (something other than subject). The totals do not necessarily add up to $100 \%$, as in the case of the editorial, only in one case does the writer combine a textual and an interpersonal Theme, while in the case of the news report, in the only case where an interpersonal Theme occurs, it occurs in conjunction with a textual Theme:

$\mathrm{NR}=$ News report; $\mathrm{E}=$ editorial

\begin{tabular}{|l|c|c|}
\hline Theme type & NR & E \\
\hline Topical Theme only & $64 \%$ & $66 \%$ \\
\hline Textual Theme & $43 \%$ & $28 \%$ \\
\hline Interpersonal Theme & $3 \%$ & $8 \%$ \\
\hline
\end{tabular}

Table 4. Theme Types in the Data

There were some differences between the two journalistic texts with respect to Theme choice. However, these differences do not all corroborate the differences mentioned in section 3. With respect to textual Themes, while Francis (1990) found a similar frequency across editorial and letters, on the one hand, and new reports on the other, in the two articles analyzed here, we can see a much higher frequency of textual Themes in the news report.

If we look at those textual Themes, an interesting pattern emerges. Of the 14 textual Themes included in the news report, 2 belong to quotes (both if, introducing a condition), and 2 are additional and. All of the rest are concessive: however, but, while, and nonetheless. In the account on Theme, textual adjuncts are seen as linking or binding clauses together, which perhaps does not to justice to their semantic role of also providing interpersonal comment. For instance, if we take the sentence from the news article, "However, Mr. Sharon gave no indication that Israel was preparing to act alone to attack Iranian nuclear facilities...", however serves as a textual Theme and adjunct, as it links to the previous clause, in which Mr. Sharon's knowledge of Iranian nuclear capabilities is made clear. The however indicates that the writer expects the reader to assume that there is the possibility that Israel is going to attack Iran's nuclear facilities, and thus that proposition by default would be expected, or normal. Thompson and Hunston (2000) suggest that conjuncts "such as and and but and subordinators such as because and although assume a common ground between reader and writer in terms of what is expected or unexpected at any given point in the discourse" (9). Thompson and Zou argue that "conjuncts reflect a more dominant role for the writer in that they guide the reader towards the type of conjunction which the writer has already decided on" (141). The function of conjuncts such as but and however is to provide a link between propositions based on how 
the writer views the expectedness of the upcoming proposition in light of the previous proposition. The writer could have left out however in the example under consideration, in which case the sentence would read as follows. "Mr. Sharon said Israeli intelligence showed Iran was near "a point of no return" in learning how to develop a weapon. $\mathrm{Mr}$. Sharon gave no indication that Israel was preparing to act alone to attack Iranian nuclear facilities". The reader would still link the two ideas given their contiguity, yet by including "however" the writer is inserting openly the opinion that, given Iran's development of a nuclear weapon, it is expected that Israel would attack. As Thompson and Zou (2000) explain: "To express the opinion that one proposition is, say, surprising in the light of the previous proposition signals explicit intrusion by the writer into the text". Here, we see how the textual and interpersonal functions blend through the use of conjuncts. Thus, the correspondent uses conjuncts in a way which not only provides cohesion for the reader, but also gives the reader glimpses into the correspondent's take on the propositions.

In this study, as in those mentioned in Section 3, there are more interpersonal Themes appearing in the editorial; in the news report, there is actually only one of these, "in fact", while in the editorial there are two: "unlike" and "handled properly". What is rather striking is that the writer of the editorial does not use this position of focus to insert his comment on the topic. Thus, in terms of multiple Theme, the correspondent seems to be providing more insights into his report (through textual Themes) than the editorialist does in the opinion piece (through interpersonal Themes, which are freely available to the editorialist). However, as we will now see, attitudes are indeed expressed throughout the clauses in the latter much more frequently than in the news report.

\subsection{APPRAISAL}

There are marked differences between the news report and the editorial in terms of APPRAISAL. The news report only contained 3 tokens of ATTITUDE which are not attributed to an outside spokesperson (the element which is being appraised is underlined):

a) Mr. Sharon's extended conversation showed tension (appreciation)

b) the subtext of the conversation is of increasing concern (appreciation)

c) Europeans seem more willing...to allow some uranium enrichment (judgement)

At the same time, the amount of reporting going on in the news report is incredibly high; in fact, nearly half (a full 49\%) of all of the topical Themes in the news report are sayers in verbal processes ${ }^{4}$; and the sayers quoted do not appear only in Theme position. Within their projections, there are indeed tokens expressing judgement and appreciation; however, the correspondent distances himself from those interpersonal expressions as he encodes them as belonging to others. He cites Mr. Sharon, American officials, Israeli officials, Dr. Mohamed ElBaradei, director general of the International Atomic Energy Agency, The White House, Israeli radio and other news reports in Israel...even countries speak, such as The United States and Iran. There is only one instance of a modalized utterance, which we 
have seen in example d) in section 3.2, with the inclusion of seem. Thus, the reporter presents a factual account mainly in terms of what was said by whom, sometimes quoted directly, sometimes paraphrased. As we have seen, he uses textual adjuncts to provide connections between the different viewpoints expressed by others, and it is through these linking words that he makes his view on what is expected or unexpected known.

The editorial, on the other hand, contains tokens of APPRAISAL and/or modality in almost every clause. There is far less recourse to the system of ENGAGEMENT than the news report; for example, the editorialist only thematises sayers in $13 \%$ of the clauses. Those sayers are for the most part anonymous settlers, whose words are used to show the difficulty of the plan to forcibly dismantle Israeli settlements in the Gaza Strip. There is one mention of Mr. Bush as a sayer, in that he publicly chided Sharon about the settlements, a verbal behavior which the editorialist judges as "absolutely correct". And, indeed, there are quite a few more tokens of JUDGEMENT running through the editorial, of Hamas (a terrorist group) of Sharon (whose ability answer unequivocally is questioned, along with his ability to handle properly the situation), of Mr. Abbas, whose capacity is also questioned (as he will have to do much more), and of the Palestinians, who come off judged rather harshly (they shoot themselves in the foot, and the editorialist, in calling on them to act sensibly, is suggesting that the possibility exists that they may not do so). There are also a number of tokens of APPRECIATION, as the situation is untenable, the plan to remove Israelis from the settlements is controversial, and so on.

\section{Conclusion}

This article sheds light on differences between two news genres, the news report and the editorial, by analyzing the textual and interpersonal function of language in two sample texts. We have seen that the major difference between the two in terms of the textual function is not the use of interpersonal Theme in the editorial, as one might expect, but rather the higher use in the news report of textual Themes. We can speculate that if linguists traditionally view conjuncts such as however and nonetheless as providing links between linguistic units, and not commenting on propositions as in the case of disjuncts ${ }^{5}$, then perhaps it is not too far fetched to assume that non-linguists use conjuncts in writing to signpost the way for their reader, without realizing the extent to which these signposts do provide interpersonal comment on propositions. We have seen in the case of the news report that the correspondent writing the particular article under analysis uses a number of conjuncts which provide an indication to his reader of what it is he finds expected/unexpected. Furthermore, the correspondent reports heavily on what other people have said, which allows him interpersonal distance from propositions recorded in his news story, and which also allows readers to understand that there are more points of view on a given proposition. At the same time, the news reporter alternates projections with unmodalized declarative clauses, with very little or no recourse to the system of APPRAISAL, which provide a monoglossic bent to propositions, suggesting that there are no 
alternative views, thereby giving an impression of factuality.

The editorial, on the other hand, uses more obvious forms of interpersonal comment, through overt tokens of JUDGEMENT and APPRECIATION, as well as through the use of modality. In the editorial, people's words and actions are considered and judged, and the editorialist urges the parties involved to take action in some way or another. The function of the editorial is to affect in some way public policy, while ostensibly the role of the news report is not. Still, through the inclusion of the various propositions reported on in "Sharon asks U.S to pressure Iran on nuclear arms", by adding in only a couple of comments through APPRECIATION (e.g. a conversation...ofincreasing concern) and by guiding readers to read propositions as expected/unexpected, the writer manages to convey a sense of urgency or worry, which indeed does seem to be one major function of many news stories. Thus, systemic functional linguistics can help us understand how language is used in the media to construct the world in specific kinds of ways.

\section{Notes}

1. Where possible, examples are taken from the data analyzed in this article; where it is not possible, data has been taken from other sources.

2. Following convention in SFL, Appraisal systems are encoded in small caps, to distinguish this technical use from non-technical uses of the terms.

3. Again, where possible, examples are taken from the data analyzed here.

4. In SFL, in an experiential analysis of the clause, the verb can represent different kinds of processes: material (processes of doing and happening); mental (sensing, seeing, feeling and thinking); verbal (saying); relational (being and having) and existential (existing). These are accompanied by different kinds of participants: for example, material processes with participants such as actors and goals; mental with sensers and phenomena; verbal with sayers; relational processes with attributes and carriers.

5. According to Thompson and Zou 2000: 123, disjuncts are traditionally viewed as providers of information as to the writer's attitude towards the proposition, and not as providers of linking across clauses; Thompson and Zou go on to demonstrate that indeed they do provide a conjunctive function.

\section{References}

Brown, Gillian and Geoge Yule (1983): Discourse Analysis. Cambridge, UK: Cambridge University Press.

Berry, Margaret (1996): “What is Theme? -- A(nother) personal view'. In M. Berry, C. Butler, R. Fawcett \& G. Huang (eds.): Meaning and Form: Systemic Functional Interpretations. Norwood, New Jersey: Ablex Publishing Company, 1-64.

Caldas-Coulthard, Carmen Rosa (1994) "On reporting reporting: the representation of speech in factual and factional narratives". In M. Coulthard (ed.) Advances in Written Text Analysis. London: Routledge, 295-308. 
Coffin, C. (2002). The voices of history: theorising the interpersonal semantics of historical discourses. Text 22 (4), 503-528.

Davies, Martin (1997): “Cohesion in literary texts”. Talk given at Saint Louis University, Madrid Campus, March 3rd, 1997.

Francis, Gill (1990): "Theme in the daily press". Occasional Papers in Systemic Linguistics, 4: 51-87.

Fries, Peter H. (1983): “On the status of Theme in English: arguments from discourse”. In J. S. Petöfi and E. Sözer (eds.): Micro and Macro Connexity of Text. Hamburg: Helmut Buske Verlag (Papers in Text Linguistics 45), 116-152.

Halliday, M.A.K. (1967): "Notes on transitivity and Theme in English. Part 2. Journal of Linguistics 3 (2): 199-244. 179-215. . (1968): "Notes on transitivity and Theme in English. Part 3. Journal of Linguistics 4 (2):

. (1985): An Introduction to Functional Grammar. London: Edward Arnold. (1994): An Introduction to Functional Grammar (2 ${ }^{\text {nd }}$ edition). London: Edward Arnold.

Halliday, M.A.K. and Christian M.I.M. Matthiessen (2004): An Introduction to Functional Grammar. (3rd edition). London: Hodder Arnold.

Hawes, Thomas and Sarah Thomas (1996): “Rhetorical uses of Theme in newspaper editorials'. World Englishes 15(2): 159-170.

Iedema, Rick, Susan Feez and Peter.R.R. White (1994) Media Literacy, Sydney, Disadvantaged Schools Program, NSW Department of School Education. Available: http://grammatics.com/appraisal/MediaLit-Appraise.doc. [accessed: February 2, 2006]

Martin, J. R. (1992): "Theme, method of development and existentiality: the price of reply". Occasional Papers in Systemic Linguistics 6: 147-183.

Martin, J.R. and David Rose (2003): Working with Discourse. London: Continuum.

McCabe, Anne and Isabel Alonso Belmonte (2000), 'Theme, Rheme and cognitive representation in Spanish and English texts. Revista Canaria de Estudios Ingleses 40: 77-94. Reprinted in clac (CÍRCULO de lingüística aplicada a la comunicación), 7 (septiembre, 2001). Revista electrónica de la Universidad Complutense de Madrid. Available:

[http://www.ucm.es/info/circulo/no7/mccabe.htm].

Thompson, Geoff and Susan Hunston (2000): “Evaluation: an introduction”. In G. Thompson and S. Hunston, eds., Evaluation in Text. Oxford: Oxford University Press, 1-27.

Thompson, Geoff and Jianglin Zhou (2000): "Evaluation and organization in text: the structuring role of evaluative disjuncts". In G. Thompson and S. Hunston, eds., Evaluation in Text. Oxford: Oxford University Press, 121-141.

White, Peter R.R. (1998) Telling Media Tales: The News Story as Rhetoric. Unpublished PhD thesis, University of Sydney. . (2005a): "Appraisal website homepage". Available: [ http://www.grammatics.com/appraisal/]. [accessed: February 23, 2006]. .(2005b): 'An introductory tour through appraisal theory'.

[http://grammatics.com/appraisal/AppraisalOutline/UnFramed/AppraisalOutline.htm]. [accessed: February 23, 2006].

. White, Peter R.R. (no date): "Media voices. Part I". Undergraduate course on Media Discourse taught at University of Birmingham. Available: http://www.journalese.org/5MediaVoices.pdf. [Date accessed: February 3, 2006]. 


\section{Appendix A}

News Article:

SHARON ASKS U.S. TO PRESSURE IRAN ON NUCLEAR ARMS

By DAVID E. SANGER; DAVID S. CLOUD CONTRIBUTED REPORTING FROM WASHINGTON FOR THIS ARTICLE AND STEVEN ERLANGER FROM ISRAEL. Published: April 13, 2005

Spreading photographs of Iranian nuclear sites over a lunch table at the Bush ranch in Texas on Monday, Prime Minister Ariel Sharon of Israel urged President Bush to step up pressure on Iran to give up all elements of its nuclear program, according to senior American and Israeli officials. Mr. Sharon said Israeli intelligence showed Iran was near "a point of no return" in learning how to develop a weapon, the officials said. However, Mr. Sharon gave no indication that Israel was preparing to act alone to attack Iranian nuclear facilities, a prospect that Vice President Dick Cheney, who was at the lunch, raised publicly three months ago.

In a conversation lasting more than an hour, Mr. Sharon argued that European nations negotiating with Iran were softening their position and may be willing to allow it to hold on to technology to enrich uranium.

American officials said the evidence Mr. Sharon presented, including aerial photographs of sites in Iran, was neither startling nor new to Mr. Bush. But they said the prime minister was clearly pressuring Mr. Bush not to allow the European negotiations with Iran to drag on.

"The Israelis consider the Iranians a big threat and they saw this as another opportunity to convey that to the president," an American official said. But among American experts familiar with the latest Israeli imagery, the official added, "no one thinks this was earth-shattering stuff".

Israeli officials declined to describe the evidence they presented, or say whether the photographs were from Israeli or American sources, commercial satellites, or from agents on the ground in Iran.

Nonetheless, Mr. Sharon's extended conversation -- bolstered by the Israeli photographs and intelligence presented by his chief military aide, Brig. Gen. Yaakov Galant -- showed tension between Israel and its biggest ally over how much time is available to deal with the issue.

While American and Israeli officials insisted Tuesday that they were in total agreement about the nature of the Iranian threat, Israel has interpreted the evidence that the two countries share in what one official called "the worst-case scenario". In describing the Iranians as on the cusp of a "point of no return," officials said, Mr. Sharon was arguing to Mr. Bush that once Iran solves some remaining technical hurdles, there will be no effective way of stopping it from ultimately building a weapon -- even if that day is years away.

"This can't be delayed much longer," a senior Israeli official traveling in Mr. Sharon's party said Tuesday. "There is very little time until the point of no return is reached".

American officials have interpreted the evidence differently. While they have accused Iran of running a secret weapons program -- under the cover of plans to build nuclear power plants for electricity -- they have told Congress that any weapon is likely to be several years away. In the most recent public testimony on the subject, on Feb. 16, Vice Adm. Lowell E. Jacoby, the director of the Defense Intelligence Agency, told Congress that "unless constrained by a nuclear nonproliferation agreement, Tehran probably will have the ability to produce nuclear weapons early in the next decade". 
Dr. Mohamed ElBaradei, director general of the International Atomic Energy Agency, said in February in the German magazine Der Spiegel that if Iran had "decided to operate a secret nuclear weapons program -- for which we, as I mentioned, have not found any evidence to date -they are likely to have a bomb in two to three years. They certainly have the know-how and the industrial infrastructure".

The White House said Monday that the subject of Iran came up over lunch, but it made no mention of the intelligence that was presented, and gave no details of the conversation. Israeli radio and other news reports in Israel gave more details earlier Tuesday, prompting American and Israeli officials to speak about the interchanges more openly.

The subtext of the conversation is an increasing concern within the administration that Israel might act pre-emptively, as it did in 1981 when it attacked Iraq's nuclear reactor at Osirak.

While American officials have rarely discussed that possibility openly, Mr. Cheney talked about it in an interview on MSNBC on Inauguration Day. "If, in fact, the Israelis became convinced the Iranians had a significant nuclear capability," he said, "given the fact that Iran has a stated policy that their objective is the destruction of Israel, the Israelis might well decide to act first, and let the rest of the world worry about cleaning up the diplomatic mess afterwards".

Mr. Sharon made no such threat at the lunch, officials said, and a senior Israeli official said Tuesday in Washington that "it is not Israel's job to lead this effort". The official warned that "what is worrisome is that there are several European countries that are beginning to think that Iran will be a member of the club, and that is a grave danger".

Mr. Sharon, officials said, made it clear to administration officials during his visit that he has little confidence in the outcome of the negotiations under way by Iran and three European nations -Britain, France and Germany. Iran has insisted that it has the right to enrich uranium under the Nuclear Nonproliferation Treaty, and will not give up that right. While there is disagreement among the Europeans themselves, they seem more willing to allow some uranium enrichment, under strict monitoring.

The United States has argued that because Iran hid so many elements of its nuclear program from the International Atomic Energy Agency for 17 years, it cannot be trusted.

"If you think that they've been running a secret weapons program, which is what we believe and the Israelis believe, than what kind of inspection system could work?" a senior American diplomat said Tuesday.

The session at the ranch also included some references to Iran's growing missile program, which gives it the ability to reach Israel. Admiral Jacoby, in his February testimony, noted that Iran already has medium-range missiles "capable of reaching Tel Aviv," and he said that by 2015, it may have "the technical capability" to develop an intercontinental ballistic missile. But he noted that "it is not clear whether Iran has decided to field such a missile".

Recently the new president of the Ukraine, Viktor A. Yushchenko, said his government had discovered evidence that the country's previous leadership secretly sold to Iran and China cruise missiles that can carry a nuclear warhead. Iran has denied it made any such purchases. 
Editorial:

Summertime in Gaza

(NYT) 651 words

Published: April 13, 2005

If the chatter among the Israelis and the Palestinians is anything to go by, this is going to be a July to remember in the Middle East. The Palestinian Authority is planning to hold local elections in just three months. Unlike the election in January that made Mahmoud Abbas president, these elections will include Hamas, the part-time terrorist and part-time civic organization that has been the bane of Israel for so many years.

As if that weren't enough, the Israeli prime minister, Ariel Sharon, is planning to start carrying out his controversial plan to remove Israelis from the Gaza Strip and a handful of West Bank settlements. Handled properly, the Gaza withdrawal could re-energize prospects for peace in the region like nothing else since, well, the death of Yasir Arafat. But, this being the Middle East, the disengagement also has the potential to throw the region back into turmoil and violence. Both $\mathrm{Mr}$. Sharon and Mr. Abbas must stand fast against extremist factions among their own people to make sure that does not happen.

Mr. Sharon must figure out how to manage the opposition to the removal of the 8,500 settlers who live among some one million Palestinians. The opposition may not be widespread, but it certainly will be vocal and perhaps violent. The prime minister has already had a taste of the emotional baggage this will bring.

During what his aides told the Israeli press was an overwrought session last week between Mr. Sharon and settlers from Gush Katif, Mr. Sharon listened, with clenched jaw, as the settlers hurled one accusation after another. One said his 12th-grade son was so distraught that he had quit school. Another said his son had quit an infantry course because he didn't want to command the evacuation of settlements. Ordering young Israeli soldiers to evacuate some settlers forcibly will be another challenge for Mr. Sharon. Yet another settler told the prime minister that his daughter had been injured and his nephew murdered in terror attacks. "In light of all these tragedies, do we also deserve this punishment?" he asked.

Mr. Sharon has to answer unequivocally: it's not an issue of punishment, but rather one of necessity. The settlements that have sprung up outside the 1967 borders -- described by one Israeli official as Israel's "playing cards" for negotiation purposes -- have done much to create the untenable situation that exists today. Israel fell in love with its playing cards, the official admitted. But to have peace, Israel must give up most of those cards.

Mr. Sharon gave no ground on Monday in the face of President Bush's insistence that Israel should not go ahead with plans to build new houses in the settlement of Maale Adumim. But Mr. Bush was absolutely correct in publicly chiding Mr. Sharon by saying the "road map clearly says no expansion of settlements". Replacing Gaza with a larger Maale Adumim is not the way to peace. Mr. Abbas, for his part, will have to do much more than just sit on the sidelines and watch the Israeli withdrawal from Gaza. He must figure out a way to stop his fellow Palestinians from shooting themselves in the foot -- as they are prone to do -- by attacking the Israeli settlers on the way out. Mr. Abbas would do well to rein in Palestinian extremists who believe they must show the world that they are driving the Israelis out by stepping up their attacks as July nears. Unless the Palestinians want Gaza to be the last Israeli withdrawal instead of the first, it would behoove them to act sensibly. 